\title{
JURIDIC REVIEW FOR THE DEVELOPMENT OF ACADEMIC TEXTS FOR AMENDMENT TO THE REGULATION OF THE REGENT OF TULUNGAGUNG CONCERNING ADMINISTRATION OF ADVERTISEMENTS
}

\section{Retno Sari Dewi ${ }^{1^{*}}$ \\ Surjanti ${ }^{2}$}

Anang Sugeng Cahyono ${ }^{3}$

Bambang Slamet Eko $\mathrm{S}^{4}$

1,2,3 Tulungagung University, Indonesia

e-mail: sarie.soegito@gmail.com ${ }^{1}$, surjanti.unita@gmail.com², akusukambahdi@gmail.com³ bambangtook@gmail.com ${ }^{4}$

*Correspondence: sarie.soegito@gmail.com ${ }^{1}$

Submitted: 05 November 2021, Revised: 11 November 2021, Accepted: 14 November 2021

Abstract. One aspect that is of concern to the Government of Tulungagung Regency is in terms of increasing Regional Original Income (PAD) through the installation of billboards. The Regent in this case as the Regional Head has the authority to make regulations relating to the administration of billboards, the policy regarding the implementation of billboards is to control urban spatial planning so that it is more organized, improve services to the community, and can protect the interests and public order, as well as increase PAD (here in after referred to as Regional Original Revenue) of Tulungagung Regency through advertisement tax revenues. Aims to review the regulation of the administration of advertisements related to licensing regarding arranging permits, installation, form, place of billboards and value advertisement tax, as well as to explain the licensing and tax mechanism on billboards and increase the Regional Original Income (PAD) of Tulungagung Regency through the advertisement tax sector. This research use desciptive qualitative approach, this research is a type of legal social research with the ROCCIPI approach. From the results of the study, it is concluded that the formation of the Regent's draft regulation requires a policy concept through an Academic Paper. Academic papers are a scientific basis and provide a direction in the preparation of public policies.

Keywords: taxes; tax laws; advertisements; academic manuscripts; public policies. 


\section{INTRODUCTION}

Law Number 23 of 2014 concerning Regional Government (UU PEMDA) provides broad autonomy for City/ Regency Governments to explore all potential resources owned by each region (Indonesia, 2014). In line with this policy, the District Government seeks to develop a financing mechanism by exploring various forms of potential financing to support regional development as well as to improve the quality of services to the community.

One aspect that is of concern to the Tulungagung Regency Government is in terms of increasing Regional Original Revenue (PAD) through the installation of billboards. Advertising is a tool used to introduce, promote, and offer goods or services produced to the public by using images and other types of patterns, to attract public attention (Kazmi \& Batra, 2009).

The role or function of billboards in trade or business according to Kyala, 2020) is influencing or persuading consumers so that they will make a purchase, creating a certain impression about the services or goods being advertised, and as a means of communication between sellers and potential buyers or consumers.

The implementation of billboards is a series of activities and arrangements that include planning, types, licensing, organizing, controlling, monitoring and controlling billboards in the context of realizing a harmonious use of urban space (Noviyanti \& Zaini, 2019). Spatial planning is a structural form and pattern of space utilization, whether planned or not (Santosa, 2020). One of the characteristics of an effective government is its commitment to enact and enforce the laws and regulations that it has made. The company seeks to promote the production of goods or services it produces to consumers. For this reason, in an effort to promote, there are many ways to do it, one of the most well-known and often seen is advertisements placed on billboards. Advertising is an inseparable part of the modern social system and society (Thadi et al., 2019).

Advertising is the work that can constructing social reality, the creation of social reality by advertising using a production model called simulation, humans are trapped in a room that they consider to be real, even though it is artificial, or a mere fantasy (Bungin, 2011). Advertisements are individuals or entities that organize advertisements for themselves or on behalf of other interested parties. When viewing these online billboards on websites and social media, some companies and individuals will conduct advertising campaigns on these media (Jawahir et al., 2021).

Advertising has developed into a communication system that is very important not only for producers of products and services but also for consumers. The ability of advertisements in conveying messages to consumers makes this field a very important role for the company's success in marketing its products and services (Wirianto, 2010).

Advertisements also have an important role for the general public about information and billboards as well as a 
382 I Juridic Review for the Development of Academic Texts for Amendment to the Regulation of the Regent of Tulungagung Concerning Administration of Advertisements

means of visual communication (Vlasenko et al., 2021). Based on this function, billboards are also an important means of communication in the city/district center, so that the procurement of billboards continues to increase without any regulation from the government so that many billboards are not in a good position in their placement.

According to (Nowghabi \& Talebzadeh, 2019) that billboards have a contribution to shape the city's landscape. In some cities, the installation of billboards will form environmental characteristics. But the installation of billboards without planning and arrangement will provide its own problems. The irregular installation of billboards creates the impression of "slum" and obscures the information to be conveyed.

Advertisements are usually erected on a piece of land. Land in question is an area on the earth's surface, including all components of the biosphere that can be considered fixed or cyclical in nature above and below the area, including the atmosphere, soil, source rock, relief, hydrology, plants and animals, as well as all the consequences caused by human activities in the past and present, all of which affect the use of land by humans at present and in the future.

Within the scope of planning, land is land that has already been designated and is generally owned and utilized by individuals or institutions for cultivation. Today, as the population continues to grow, land is the most important natural resource Increase without increasing the area (Soimin, 2008). Land has a limited nature that is not increasing or decreasing. Land has a close relationship with the designation of billboards, marked by the more advanced an area, the more people who use billboards, which indirectly affects land use in an area, both City/Regency (Ramadhan, 2018).

The implementation or placement of advertisements using public spaces must be followed by the interests of the general public who want to use public spaces or enjoy the beauty of the city. Public space itself is not only a place to place advertisements, but state facilities provided to the wider community. Law No. 26 of 2007 concerning Spatial Planning, public space can be said to be Public Green Open Space or Public Non-Green Open Space, which institutionally must be provided by the government in land allocation in cities in Indonesia ( $\mathrm{No}, 26$ C.E.).

Public green open space itself is explained in Article 29 Paragraph 1 of Law Number 26 of 2007 concerning Spatial Planning, namely Public green open space is a green open space owned and managed by the city regional government which is used for the benefit of the community in general. Public green spaces include, among others, city parks, public cemetery parks, and green lines along roads, rivers, and beaches (Sidauruk, 2019).

Private green open space includes, among others, gardens or yards of houses or buildings belonging to the public or private which are planted with plants (Pirngadie et al., 2016). Meanwhile, NonGreen Open Space is an open space in the city or urban area that is not included in 
the green open space category, namely in the form of hardened land or in the form of water bodies (Umum, 2007).

Public spaces can be in the form of roads (including pedestrians), pavements (pavements), public squares, and parks. This means that public open green spaces such as roads and parks as well as public non-green open spaces such as plazas and public squares can be functioned as public spaces. Meanwhile, according to (Habermas, 2020) public space for him is a space that bridges between the state and civil society. This room is a universal room, where people gather to discuss anything that needs to be discussed.

The installation of billboards has its own procedures and procedures and in its implementation is also related to several parties with an interest in its installation, including:

\section{Government Party}

The government referred to here is the local government (district, city) where the billboard will be installed. The city/district government has the authority to issue a permit for the installation of the billboard in accordance with the local regulation issued by the Regent/Mayor, who then delegates it under the authority of the City Parks and Spatial Planning Service.

2. Advertisement Organizing Party

The party that organizes the advertisement of the Advertising company in its operation is obliged to submit an application to obtain a business license to install billboards by first completing the various requirements that have been determined.

3. Product and Service Company Parties

Product and service companies are parties that own and market a product and service to be known by the public.

With the enactment of Law Number 23 of 2014 which is directed at accelerating the realization of community welfare through improving services, empowerment, and community participation, as well as increasing regional competitiveness by taking into account the principles of democracy, equity, justice, and the uniqueness of an area within the system of the Unitary State of the Republic of Indonesia (Indonesia, 2014).

The development of a region can no longer be confined to the central government, but local governments are required to be more creative in exploring and managing their potential and smarter in making regulations for their regions in order to realize community welfare, improve community services and increase regional competitiveness in relation to tax imposition. (Wu, 2018)

Regional taxes and regional levies are important sources of regional income to finance the implementation of regional government (Siregar et al., 2020). Regional tax policies (and regional levies) are implemented based on the principles of democracy, equity and justice, community participation, and accountability by taking into account regional potential.

Regional taxes and levies currently in effect must refer to Law Number 28 of 2009 concerning Regional Taxes and Levies (Purwandari, 2021). Based on Law Number 28 of 2009 concerning Regional Taxes and 
384 I Juridic Review for the Development of Academic Texts for Amendment to the Regulation of the Regent of Tulungagung Concerning Administration of Advertisements

Regional Levies Article 2 paragraph (2) explains that regency/city regional taxes consist of:
a. Hotel

b. Taxes Restaurant

c. Taxes Entertainment

d. Taxes Advertising

e. Taxes Street Lighting

f. Taxes Non-Metal Mineral and Rock

g. Taxes Parking

h. Taxes Groundwater Taxes

i. Swallow's Nest

j. Tax Rural and Urban Taxes Land and Building

k. Land and Building Rights Acquisition Fees

There is one type of tax that is attractive to all of the above taxes, namely the advertisement tax. Advertising tax is a tax levied by the region on the implementation of advertisements based on tax regulations determined by the region through objects, tools, deeds or media with commercial purposes by introducing or attracting people's attention to an item or service in a public place (Astuti, 2020).

Advertising tax has an important role in local revenue. Realization of local revenue always changes every year, even though in every 7 years the local government collects taxpayers who do not carry out their obligations in terms of paying taxes (Isti \& Kusuma Wardani, 2014).

Advertising tax is levied on all advertising administrations by individuals or entities. Advertisements can be held directly by individuals or entities that use advertisements for their own interests, the advertisement taxpayer is the individual. If the advertisement is implemented through a third party (advertising service company), then the third party becomes the advertisement tax payer (Hernawan \& Tanto, 2019).

According to (Jawahir et al., 2021) the income from the advertisement tax is obtained from the rental value of the advertisements installed with the advertisement rental rates based on the location of the advertisement installation, the duration of the advertisement installation, and the type of advertisement size. Parties who use advertising services from the fields of education, industry, hospitality, entertainment, banks and financial institutions, transportation, communication and government parties.

Advertising Tax is a levy imposed on the administration of advertisements (Nurmayasari \& Handayani, 2010). Advertisement Tax is imposed on the grounds that billboards are used to introduce, recommend or praise an item, service or person placed or which can be seen, read and/or heard from a public place, except for those carried out by the Government (Kumala, 2019).

Economic growth in the region is progressing rapidly, so that the advertisement tax in the future is projected to have good prospects. To see this prospect, it is used by looking at the product and regional factors. Advertising tax is one of the potential sources of local revenue and has a very important role in increasing local revenue (Taras et al., 2017). Advertisement tax as a contributor to local revenue, although its realization is not as large as compared to other types of local taxes. On this basis, the advertisement tax 
can be used as an increase in local revenue (Usman et al., 2020).

From the various descriptions above, the need for policies regarding the implementation of billboards is to control the city's spatial planning so that it is more organized, improve services to the community, and can protect the interests and public order, and increase PAD (here in after referred to as Regional Original Revenue) of Tulungagung Regency through advertisement tax revenues.

The objectives of this study are to examine the regulation of the administration of advertisements related to licensing regarding arranging permits, installation, form, place of advertisements and the value of advertisement tax. To regulate licensing and tax mechanisms regarding billboards and to increase the Regional Original Revenue (PAD) of Tulungagung Regency through the advertisement tax sector. Provide regulatory guidelines in organizing billboards in Tulungagung Regency.

The difference between this study and the previous one is that this research provides an overview, although legally formally, the preparation of academic texts for the regent's draft regulation is not a necessity, but the existence of an academic text of a regional regulation made by the Regional Government together with the DPRD or made by the Regent himself has an important value. Which is very strategic in the formation of good legislation.

In practice that has occurred so far, academic documents are only used as formal requirements and tend to be ruled out by legal product makers, and this often happens, because in the process of compiling legal products in the form of legislation using the Top Down model. The maker of legal products, in this case, the government determines and decides, while the community only acts as an implementing tool. The application of the Top Down model will not only have an impact on strict and strict law enforcement but also on the implementation of the legal product.

\section{METHODS}

In this study using a qualitative descriptive approach (Nawawi, 2007), included in the type of social legal research or empirical juridical. This method begins with normative research on library and field research on licensing and tax collection regulations that are not burdensome in Tulungagung Regency, Collecting data on entrepreneurs and billboard users in the Tulungagung Regency area. The implementation of billboards in Tulungagung Regency.

The types of data used in this study are primary data and secondary data. Primary Data is data obtained directly from the first source. Related to the problems of this research, the primary data were obtained from officials related to the establishment of regional regulations regarding the administration of billboards in Tulungagung Regency. The nature of the data used is according to Soerjono Soekanto's opinion, obtained from secondary data consisting of 3 (three) legal materials, namely:

a. Primary Legal Materials related to Tax regulations

b. Secondary legal materials that provide 
386 I Juridic Review for the Development of Academic Texts for Amendment to the Regulation of the Regent of Tulungagung Concerning Administration of Advertisements

an explanation of primary legal materials. As for what is used in this study are journals, literature, books, internet, and so on related to the Formation of Regional Regulations on Regional Taxes of the Tulungagung Regency Government.

c. Tertiary legal materials are materials that provide instructions and explanations for primary and secondary legal materials. Tertiary legal materials such as the Big Indonesian Dictionary, Legal Dictionary, and Encyclopedias.

In qualitative research, the stages of data analysis include:

1. Data reduction.

Data reduction is the activity of sharpening, classifying, directing and removing unnecessary data and organizing data in such a way that final conclusions are obtained and verified. Data reduction was carried out continuously during the study even before the data was actually collected.

2. Presentation of data (data display)

Presentation of data to find meaningful patterns and provide the possibility of drawing conclusions and taking action.

3. Conclusion drawing or verification.

The analysis activities at this stage are drawing conclusions and verification. The analysis carried out during data collection and after data collection is used to draw conclusions so that they can find patterns about events that occur.

The approach used in the preparation of this Academic Paper is a normative juridical approach using the ROCCIPI approach. The ROCCIPI approach method is a problem solving method by (Seidman et al., 2001). ROCCIPI which is used to examine a statutory regulation with 7 (seven) categories, namely rule (regulation), opportunity, capacity, communication, interest, process, and ideology. Legislative drafting for demographic social change to acquire the skills they needed as a facilitators to instituionalize an on-going learning process to strengthen their countries' capacity to produce effective laws (Seidman et al., 2001).

The ROCCIPI categories contain the following meanings:

1. Rules.

Analyzing all regulations governing or related to problematic behavior, this is done to find out the weaknesses contained in the existing regulations.

2. Opportunity Analyze

opportunities for problematic behavior to occur.

3. Capacity

Analyze the possibility of problematic behavior due to the ability factor.

4. Communication

Problem behavior may arise due to the actor's ignorance of the rules. It should also be analyzed in order to find the cause of the problematic behavior.

5. Interest

This category is useful for explaining the viewer's view of the consequences and benefits of each behavior. This view of the cast may be the cause of the problematic behavior.

6. Process

Process categories are also a cause 
of problematic behavior. There are four main processes, namely: the input process, the conversion process, the output process, and the feedback process. The input process concerns anyone who is asked for input. The conversion process is anyone who filters and considers existing input to be used as a basis for making decisions. The output process concerns who and in what way decisions will be made. The feedback process concerns who is asked for feedback.

7. Ideology

This category refers to a set of values held by a society to feel, think, and act.

\section{RESULTS AND DISCUSSION}

The quality of the material of a law is an integral part of the law-making process. Understanding of quality is how to anticipate the possibility of a law being forced to be revised in the short term, long or sustainable validity, synergy with other laws and regulations, as well as synchronization between norms in the law itself. The academic essay will explain the reason, fact or background of the problem or business in order to encourage the preparation of the problem or the things to be exchanged so that it is indispensable and urgent to supervise in statutory regulations.

The academic paper also outlines the substance, materials and scope of the regulations to be formulated. By understanding the essence of the academic text, one can see the scientific basis for forming the draft law, which will then be proposed and discussed in the DPR (Basyir, 2014).

According to Harry Alexander (Gusman, 2011) said that the position of academic manuscripts is:

a. initial material that contains ideas of urgency, approach, scope and material content of a regional regulation.

b. The consideration material used in the application for an initiative permit for the preparation of a Raperda/other Regional Legal Product Draft to the Regional Head.

c. The basic material for the preparation of the Raperda/Draft of Legal Products.

In forming the Regent's regulation regarding the Implementation of Billboards in Tulungagung Regency, it is necessary to analyze several related laws and regulations, both vertically and horizontally. (3) This article authorizes the state to regulate matters relating to the use of space within the territory of the Unitary Republic of Indonesia for the benefit of the people's prosperity, in the provisions of article 18 paragraph 5 local governments are given the freedom to explore their potential, both natural resources and human resources. Furthermore, Law 26 of 2007 (Umum, 2007), regulated in article 2 relates to the principles in spatial planning are:

1. Integration

2. harmony,

3. balance

4. sustainability

5. empowerment

6. effectiveness

7. Openness

8. togetherness and partnership

9. protection of public interests 
388 I Juridic Review for the Development of Academic Texts for Amendment to the Regulation of the Regent of Tulungagung Concerning Administration of Advertisements

10. legal certainty and justice

Then in article 34 it can be seen that all forms related to spatial planning, each administrative area must have minimum service standards and environmental quality standards. In Law 28 of 2002 concerning Buildings relating to the implementation of advertisements, especially Article 14 paragraphs (1), (2), (3), and (4) it is stated that pay attention to the harmony and harmony of the appearance of the building and the outside of the building with the surrounding environment.

The regulation on the implementation of advertisements is also regulated in Law 28 of 2009 concerning regional taxes and advertisements, the establishment of the law is intended to expand regional authority in the field of taxes and retribution by expanding the regional tax base and regional authority in determining tax rates. It is also regulated in the Tulunggaung Regency Regional Regulation Number 11 of 2012 concerning the 2012-2023 Regional Spatial Plan for Tulungagung Regency.

Therefore, it is necessary to prepare an Academic Manuscript which serves to direct the scope of the content of the Regent's Draft Regulation to be formed. The direction of the Regent's Draft Regulation concerning the implementation of Billboards in Tulungagung Regency is to realize the existence of regulations that can be used as references and guidelines for related parties in implementing changes or adjustments to the existence of related regulations in Tulungagung Regency. The content material in the Regent's Draft

Regulation concerning the
Implementation of Billboards in Tulungagung Regency which is contained in the Academic Paper includes:

1. Chapter 1 General Provisions

2. Chapter II Types of Advertisements

3. Chapter III Provisions for Advertisement Installation

4. Chapter IV Licensing

5. Chapter V Obligations and Prohibitions

6. Chapter VI Rent Value and Calculation of Advertising Tax

7. CHAPTER VII Tax Reduction

8. Chapter VIII Classification of Regions

9. Chapter IX Tax Period

10. Chapter X Unloading Guarantee

11. Chapter XI Guidance and Supervision

12. Chapter XII Control of Advertising Implementation

13. Chapter XIII Community

14. Participation Chapter XIV Administrative Sanctions

15. Chapter XV Transitional Provisions

16. Chapter XVI Closing Provisions.

\section{CONCLUSIONS}

Based on the descriptions in the chapters above, it can be concluded that in the formation of the Regent's Draft Regulation on the Implementation of Advertisements in Tulungagung Regency, a policy concept through an Academic Paper is needed. Academic Papers are the scientific basis and provide a direction in the preparation of public policies. The regent's draft regulation is not a necessity, but the existence of an academic text of a regional regulation made by the Regional Government together with the DPRD. The 
role of stakeholders including the involvement of academics and experts as well as local governments in the preparation of academic documents is something that must be done in order to obtain information and input, so as to produce better results based on community input and development.

\section{REFERENCES}

Astuti, A. (2020). Analysis of Effectiveness and Contribution of Advertisement Tax Collection on Original Regional Income. JASa (Jurnal Akuntansi, Audit Dan Sistem Informasi Akuntansi), 4(3), 338-346.

Basyir, A. (2014). The importance of academic script in the statutes formatting to realize aspirasional and responsive law. Jurnal IUS Kajian Hukum Dan Keadilan, 2(2).

Bungin, B. (2011). Metodologi Penelitian Kuantitatif (Komunikasi, Ekonomi, dan Kebijakan Publik Serta Ilmu-ilmu Sosial Lainnya.

Gusman, D. (2011). Urgensi Naskah Akademik Dalam Pembentukan Peraturan Perundang-Undangan Yang Baik. Masalah-Masalah Hukum, 40(3), 297-304.

Habermas, J. (2020). The public sphere. Routledge.

Hernawan, E., \& Tanto, A. (2019). Analysis of the Influence of Restaurant Taxes, Advertising Taxes and Regional Lovies on the Original Income of South. ECoFin, 1(1), 42-54.

Indonesia, R. (2014). Undang-Undang Nomor 23 Tahun 2014 tentang.
Pemerintahan Daerah.

Isti, D. U., \& Kusuma Wardani, D. (2014). Pengaruh Pajak Reklame dan Retribusi Parkir terhadap Pendapatan Asli Daerah Kabupaten Bantul.

Jawahir, R. P., Haruni, C. W., \& Esfandiari, F. (2021). ANALYSIS ON THE IMPOSITION OF ONLINE REKLAME TAX ACCORDING TO LAW NUMBER 28 OF 2009. Indonesian Journal of Law and Policy Studies, 2(1), 12-27.

Kazmi, S. H. H., \& Batra, S. K. (2009). Advertising and sales Promotion. Excel Books India.

Kumala, R. (2019). Analisis Efektifitas Pajak Reklame Dalam Meningkatkan Penerimaan Pajak Daerah di Kota Bekasi. Jurnal Reformasi Administrasi: Jurnal Ilmiah Untuk Mewujudkan Masyarakat Madani, 6(1), 38-41.

Kyala, R. S. (2020). The Role of Billboard Advertisements in Promoting Telecommunications Companies in Tanzania: A Case Study of TTCL and Airtel Tanzania Billboards. The Open University of Tanzania.

Nawawi, H. (2007). Metode Penelitian di Bidang Sosial. Yogyakarta: Gajah Mada University Press.

No, U.-U. (26 C.E.). Tahun 2007 tentang. Penataan Ruang, 60, 67.

Noviyanti, R., \& Zaini, Z. (2019). IMPLEMENTATION OF RECLAME TAX COLLECTION POLICY IN TAX AND RETRIBUTION SERVICE UNITS OF CENGKARENG REGION, JAKARTA BARAT ADMINISTRATION CITY. JILPR Journal Indonesia Law and Policy Review, 1(1), 1-18. 
Nowghabi, A. S., \& Talebzadeh, A. (2019). Psychological influence of advertising billboards on city sight. Civil Engineering Journal, 5(2), 390-397.

Nurmayasari, D., \& HANDAYANI, H. R. (2010). Analisis penerimaan pajak reklame Kota Semarang. UNIVERSITAS DIPONEGORO.

Pirngadie, B. H., Unpas, D. P. W. K., \& Achmad Firmansam Bastaman, D. P. W. K. (2016). Pemanfaatan Dan Penyediaan Ruang Terbuka Hijau Untuk Mengurangi Pencemaran Udara. Fakultas Teknik Unpas.

Purwandari, E. (2021). Implikasi UndangUndang Nomor 28 Tahun 2009 Tentang Pajak Daerah Dan Retribusi Daerah Terhadap Penerimaan Bphtb Dan Pelayanan Pertanahan Studi di Kabupaten Pulang Pisau, Provinsi Kalimantan Tengah. Sekolah Tinggi Pertanahan Nasional.

Ramadhan, K. (2018). Studi Lokasi Potensial Reklame Luar Ruangan Di Koridor Strategis Kota Sumedang. Fakultas Teknik.

Santosa, D. P. (2020). Penataan Ruang Melalui Pendekatan Administrasi Publik. Inteligensia Media (Kelompok Penerbit Intrans Publishing).

Seidman, A., Seidman, R. B., \& Abeyesekere, N. (2001). Legislative drafting for democratic social change. Kluwer Law International BV.

Sidauruk, T. (2019). Kebutuhan ruang terbuka hijau di Perkotaan. Jurnal Geografi, 4(2), 79-94.
Siregar, R. T., Sinaga, R. S., Nasution, I. R., Nasution, C., Panjaitan, F., \& Modifa, I. (2020). Regional Development Environment: Implementation, Realization \& Contribution of Revenue in Pematangsiantar. IOP Conference Series: Earth and Environmental Science, 469(1), 12052.

Soimin, S. (2008). Status hak dan pembebasan tanah.

Taras, T., Artini, S., \& Gede, L. (2017). Analisis pendapatan asli daerah (PAD) dalam upaya pelaksanaan otonomi daerah di Kabupaten Badung Bali. Udayana University.

Thadi, R., Novaldi, R. A., \& Fitria, R. (2019). Commodification of Religion And CultACure On Television Advertising. Multicultural Education, 5(1).

Umum, D. P. (2007). Undang-Undang Nomor 26 Tahun 2007 tentang Penataan Ruang. Kementerian Hukum Dan HAM RI. Jakarta.

Usman, M. Y., Wibowo, A. D., Laksana, W. U., Yusriadi, Y., \& Sahid, A. (2020). Local government levy optimization. Proceedings of the International Conference on Industrial Engineering and Operations Management.

Vlasenko, N. A., Voskresenska, O. Y., \& Vlasenko, A. L. (2021). Ensuring Competitiveness Of Enterprises Through The Design Of External Advertising As A Means Of Marketing Communication. Economic Innovations, 23(2 (79)), 43-50.

Wirianto, L. (2010). Peran Reklame/lklan Dalam Mempromosikan Produk dan Jasa. Graha Llmu, Jakarta. 
Wu, F. (2018). Planning centrality, market instruments: Governing Chinese urban transformation under state entrepreneurialism. Urban Studies, 55(7), 1383-1399.

(c) (7) (2) 2021 by the authors. Submitted under the terms and conditions of the Creative Commons Attribution (CC BY SA) license (https://creativecommons.org/licenses/by-sa/4.0/). 